\title{
The Biological Treatment of Young Leachate Using an Anaerobic-Aerobic Process
}

\author{
Iva Yenis Septiariva ${ }^{1}$ and Enri Damanhuri ${ }^{1}$ \\ Department of Environmental Engineering, Institut Teknologi Bandung \\ Jl. Ganesha 10, Bandung, Jawa Barat 40132, Indonesia
}

\begin{abstract}
One of the most important problems in Municipal Solid Waste Management in Indonesia is the final process in the landfill. Generally, landfilling remains the primary disposal method and mostly carried out with open dumping. The impacts of landfill is long-term due to the potential of landfill to pose leachate that can contaminate ground water and environment. This paper presents the results of the analyses of leachate treatment from waste reactor in laboratorium scale illustrating young leachate. A biological treatment with the integration of anaerobic-aerobic process, nitrification and denitrification was successfully developed to treat young leachate. The operation time is 21 days for anaerobic reactor and 12 days for aerobic reactor. The removal efficiency for COD, ammonia-nitrogen, TKN, total phosphate, nitrite and nitrate for anaerobic process were $82.59 \%, 27.54 \%$, $17.81 \%, 3.61 \%, 75.28 \%$ and $89.17 \%$. The combination of anaerobic-aerobic process for young leachate showed removal efficiencies of COD, ammonia-nitrogen, TKN, nitrite and nitrate were 97.59\%, 85.5\%, 83.56\%, 13.19\%, $33.02 \%$, and $54.57 \%$ respectively.
\end{abstract}

Keywords: young leachate, landfill, anaerobic, aerobic

\section{Introduction}

Leachate can be defined as a liquid produced from natural moisture, water present in organic material residues, biological degradation of organic matter, water infiltration from cover layer, and inner layer of landfiil containing dissolved and suspended matter [1]. Leachate will not release from disposed waste before the water holding capacity of the waste is exceeded that contains high organic concentration, inorganic macro components, heavy metals, and xenobiotic organic compounds [2]. Leachate formation conditions and their composition are highly complex and varied depending on a number of factors like environmental conditions, waste characteristics, operations of the landfill, especially the dynamics of the decomposition process occurring within the disposed waste cell [3]. When refuse is buried in a landfill, a complex of biological and chemical reactions occur as the refuse decomposes. There are two phases such as acidic and methanogenic phases. The acid phase has low $\mathrm{pH}$ characteristics, high organic acid content, $\mathrm{BOD}_{5} / \mathrm{COD}$ ratio of 0.7 and high heavy metals. The stable methanogenic phase has $\mathrm{pH} 6-8, \mathrm{BOD}_{5} / \mathrm{COD}$ ratio lower than 0,2 and highly contaminated with ammonia [4]. The primary environmental impact related to landfill leachate are groundwater and surface water pollution. Untreated leachate is a hazard to the environment. Technologies for landfill leachate treatment include biological, physical and chemical treatment. Therefore, the objective of this study was to investigasi the anaerob-aerob biological treatment of young leachate.

\section{Research Method}

\subsection{Artificial Leachate from Reactor (Laboratory Scale) which Describes Young Leachate}

Artificial rain was maded from destilled water that saturated carbondioxide gases. Then artificial rain put in reactor that has contained waste. Artificial rain simulation was more representative of environmental conditions. In this study, artificial leachate accumulation was taken after leachate in the waste reactor accumulated for one week.

\subsection{Reactor Design}

Anaerobic-aerobic process scheme series is shown in Figure 1. The biomass volume and leachate volume ratio is $1: 4$ with a total volume of $15 \mathrm{~L}$ for anaerobic and $10 \mathrm{~L}$ for aerobic processes. Anaerobic reactor in the form of a tube measuring $58 \mathrm{~cm}$ height, diameter $19 \mathrm{~cm}$; equipped with submersible pumps and nitrogen gas cylinders. Aerobic reactor with height $58 \mathrm{~cm}$ and diameter $19 \mathrm{~cm}$ with aerator pump for oxygen supply. 
Anaerobic biological processes are performed until the COD concentration reach steady-state. Furthermore, the anaerobic process is continued into the aerobic reactor in batch until the COD removal is constant.

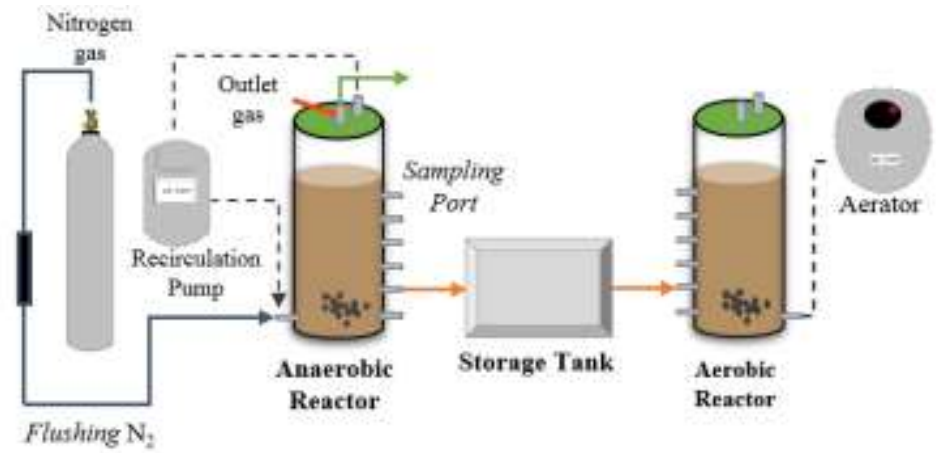

Fig. 1: Scheme of reactor variation I: biological anaerob-aerob.

\section{Result and Discussion}

\subsection{COD Removal and VSS formation}

The reduction of artificial leachate from reactor representing young leachate during anaerobic biological process to aerobic process can be seen in Figure 2. The anaerobic and aerobic detention time were 26 days and 14 days. The initial concentrations of COD at $\mathrm{t}=0 ; \mathrm{t}=18$ days and $\mathrm{t}=21$ days were $34,560 \mathrm{mg} / \mathrm{L} ; 5,888 \mathrm{mg} / \mathrm{L}$ and $6,016 \mathrm{mg} / \mathrm{L}$ respectively. Changes in COD concentration at 24-26 days showed fluctuations that did not reach more than $10 \%$. The efficiency of COD removal at $\mathrm{t}=18$ days and the end of running is $82.96 \%$ and $82.59 \%$. Furthermore, in aerobic process, COD concentration $\mathrm{t}=8$ days was $880 \mathrm{mg} / \mathrm{L}$ and at end of running aerob 832 $\mathrm{mg} / \mathrm{L}$ with efficiency of COD removal $85.37 \%$ and $86.17 \%$. The total COD efficiency of the anaerob-aerobic process was $97.59 \%$ during the 33 days detention time.

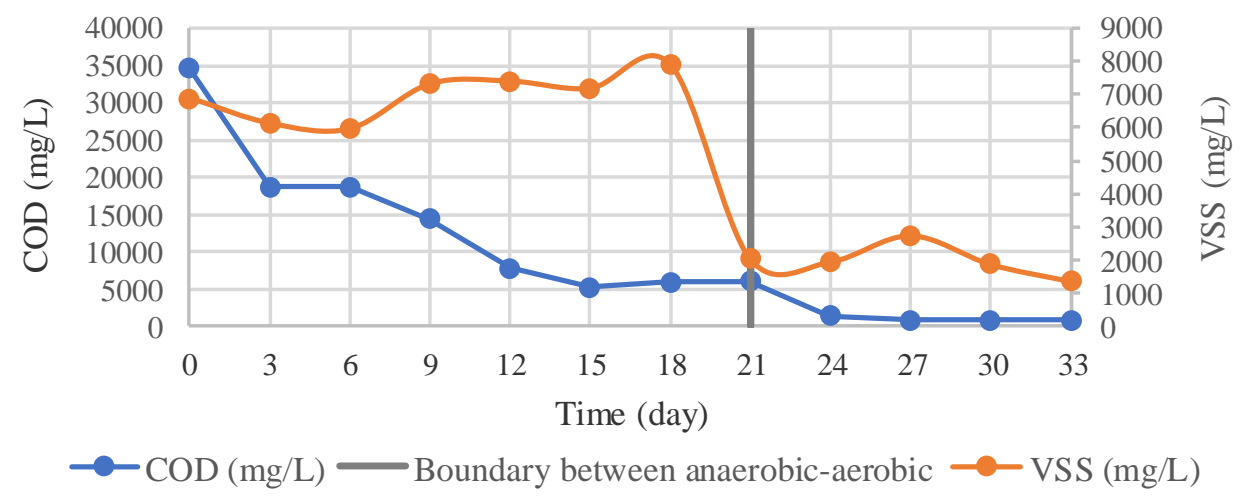

Fig. 2: COD removal and MLVSS formation

Figure 2 show the organic material in young leachate is very easily degraded under anaerobic conditions (80\%-90\% removal efficiency) in batch scale experiments. The young leachate COD fraction left in the anaerobic or aerobic process may comprise hih molecular weight organic such as fulvic and humic materials [5]. High concentration of COD are able to stimulate the growth of microbes which consume more readily decomposed organic compounds [6]. The VSS (volatile suspended Solid) value during the process tends to fluctuate, VSS is stable at range above $6,000 \mathrm{mg} / \mathrm{L}$ for anaerobic process meanwhile $2,000 \mathrm{mg} / \mathrm{L}$ for aerobic process. The inclining and declining of the biomass occurred during process because the biomass in the system adapt with the treated organic matter. Based on the trend of COD decrease, biological process are potentially applicable to remove organic compound in artificial leachate from reactor indicating the young. 


\subsection{Nutrient Removal (TKN; Ammonia; and Total Phosphate)}

The trend of TKN (Total Kjeldahl Nitrogen), ammonia and total phosphate decrease during the combination of anaerobic-aerobic biological process can be seen Figure 3. The formation of nitrit and nitrat in anaerob-aerob combination process are shown in Figure 4.

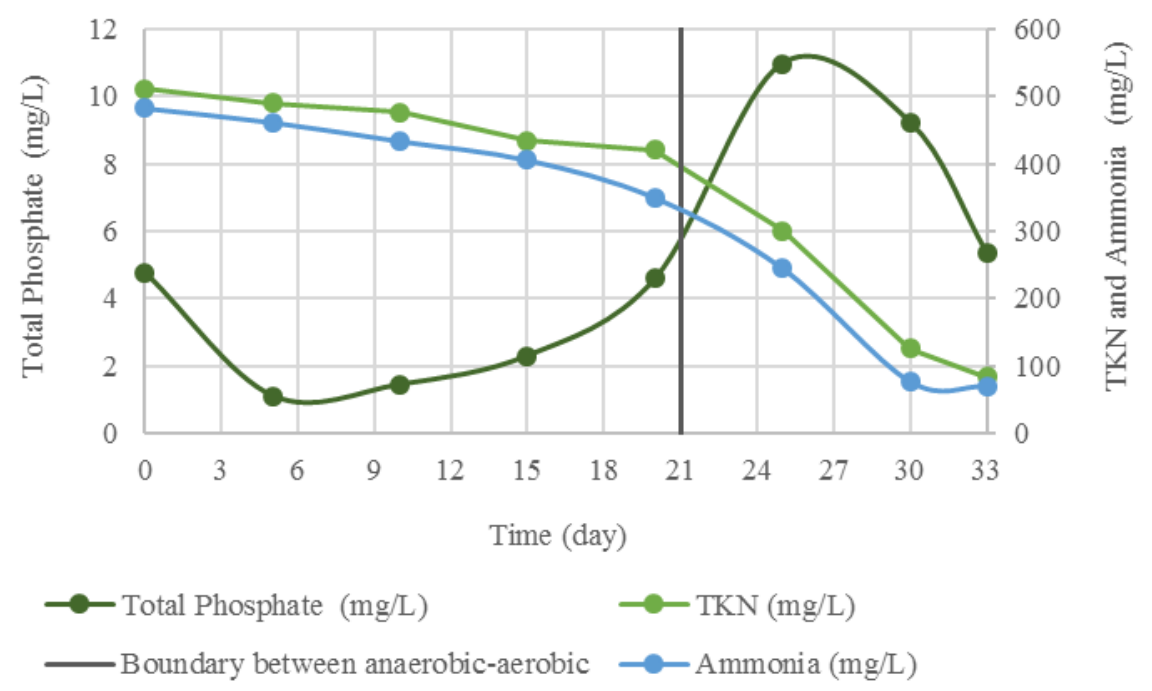

Fig. 3: Change of TKN, ammonia and total phosphate

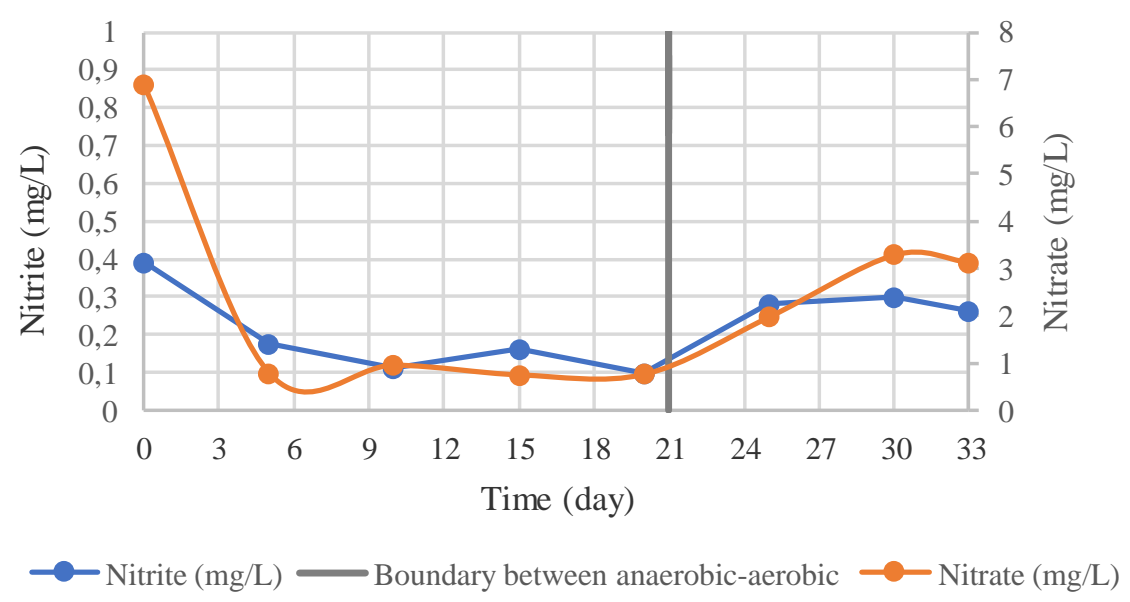

Fig. 4: Formation of nitrite and nitrate

The initial concentrations of $\mathrm{TKN}$ at $\mathrm{t}=0 ; \mathrm{t}=15$ days and $\mathrm{t}=20$ days were $511 \mathrm{mg} / \mathrm{L} ; 434 \mathrm{mg} / \mathrm{L}$ and $420 \mathrm{mg} / \mathrm{L}$ while the concentrations of ammonia were $483 \mathrm{mg} / \mathrm{L} ; 406 \mathrm{mg} / \mathrm{L}$ and $350 \mathrm{mg} / \mathrm{L}$ respectively. In aerobic process TKN and ammonia concentration were $126 \mathrm{mg} / \mathrm{L}$ and $84 \mathrm{mg} / \mathrm{L}$ for TKN parameter and $77 \mathrm{mg} / \mathrm{L}$ and $70 \mathrm{mg} / \mathrm{L}$ for ammonia parameter. Total efficiency removal of TKN and ammonia in anaerobic process were 17.81 and $27.54 \%$. Total efficiency removal of TKN and ammonia in anaerob-aerob combination process were $83.56 \%$ and $85.5 \%$. In anaerobic process, the decrease of TKN and ammonia concentration is caused by nitrogen uptake for microorganism cell formation and denitrification. Removal efficiency of total phosphate was $3.61 \%$ with the initial and final concentration were $4.76 \mathrm{mg} / \mathrm{L}$ and $4.59 \mathrm{mg} / \mathrm{L}$ in anaerobic process respectively. The organic phosphate and polyphosphate are converted to orthophosphate. In the anaerobic process process, nitrite concentration at $\mathrm{t}=0$ days was $0.39 \mathrm{mg} / \mathrm{L}$ while $\mathrm{t}=21$ days, the removal efficiency was $75.28 \%$ with nitrite concentration $0.096 \mathrm{mg} / \mathrm{L}$. The total removal efficiency of nitrite was $33.02 \%$ with the final concentration in 
aerobic process was $0.26 \mathrm{mg} / \mathrm{L}$. Figure 4 gives the decrease of nitrate concentration from concentration 6.88 $\mathrm{mg} / \mathrm{L}$ to $0.74 \mathrm{mg} / \mathrm{L}$ for 20 days; it indicates a denitrification reaction. The nitrate concentration in aerobic process at $\mathrm{t}=0$ was $1.96 \mathrm{mg} / \mathrm{L}$, after 11 days the concentration become $3.12 \mathrm{mg} / \mathrm{L}$. There is an increase concentration of nitrite and nitrate at the end of the aerobic process which depicts nitrification-denitrification reaction resulting nitrite accumulation and nitrate formation in the medium.

\subsection{Conclusion}

Artificial leachate produced from waste reactor (laboratory scale) describing young leachate in acidogenesis condition. The combination of anaerobic-aerobic process is most appropriate applied to young leachate treatment with removal efficiencies of organic parameters such as COD, ammonia-nitrogen, TKN, nitrite and nitrate were $97.59 \%, 85.5 \%, 83.56 \%, 13.19 \%, 33.02 \%$, and $54.57 \%$ respectively.

\section{References}

[1] Yao. Peng, "Perspectives on technology for landfill leachate treatment," Arabian Journal of Chemistry, vol. 10, pp. 2567-2574, 2013.

[2] Rasool. M A., Tavakoli. B., Chaibakhsh. N., Pendashteh. A R., and Mirroshandel. A.S., "Use of a plant-based coagulant in coagulation-ozonation combined treatment of leachate from a waste dumping site," Ecological Engineering, vol. 90, pp. 431-437, 2016.

https://doi.org/10.1016/j.ecoleng.2016.01.057

[3] Muller. G. T., Giacobbo. A., Chiaramonte. E.A., Rodrigues. M.A.S., Meneguzzi. A., and Bernardes. A.M., “The effect of sanitary landfill leachate aging on the biological treatment and assessment of photoelectrooxidation as a pretreatment process," Waste Management, vol. 36, pp. 177-183, 2015.

https://doi.org/10.1016/j.wasman.2014.10.024

[4] Renou. S., Givaudan. J.G., Poulain. S., Dirassouyan, F., and Moulin. P., "Landfill leachate treatment: Review and opportunity," Journal of Hazardous Materials, vol. 150, pp. 468-493, 2008.

https://doi.org/10.1016/j.jhazmat.2007.09.077

[5] Kettunen. R.H., Hoilijoki. T.H., and Rintala, J.A., "Anaerobic and sequential anaerobic-Aerobic treatments of municipal landfill leachate at low temperature," Bioresource Technology, vol. 58, pp. 31-40, 1996

https://doi.org/10.1016/S0960-8524(96)00102-2

[6] El-Gohary. F.A, and Kamel. G, "Characterization and biological treatment of pre-treated landfill leachate," Ecological Engineering, vol. 94, pp. 268-274, 2016.

https://doi.org/10.1016/j.ecoleng.2016.05.074 